\title{
Racism: A Virulent but Curable Social Disease
}

\author{
Angela J. Hattery, Timothy McGettigan, and Earl Smith ${ }^{1}$
}

In this paper, we argue that race is a destructive biological illusion that is better understood as a form of Durkheimian deviance than as a meaningful form of biological differentiation. Without question, there are significant differences among human social groups, however, those differences are sociological rather than biological in nature. We will analyze the tennis careers of Venus and Serena Williams to repudiate new and old eugenicist misanthropy and instead illustrate that positive and negative human attributes are determined by sociological success factors rather than biological attributes. Further, we will emphasize that the deleterious consequences of socio-racial differentiation are aggravated by the Thomas Theorem ("If men define situations as real, then they are real in their consequences"). We will conclude by drawing upon Jane Elliot's work to illustrate that racism is rooted in malevolent social constructions, and, as such, racism is a curable, or "deconstructable," social disease. [Article copies available for a fee from The Transformative Studies Institute. E-mail address: journal@transformativestudies.org Website: http://www.transformativestudies.org (C2014 by The Transformative Studies Institute. All rights reserved.]

KEYWORDS: Racism, Athletic Performance, Darwin, Williams Sisters, Tennis, Thomas Theorem, Jane Elliot.

Potential doesn't win a gold medal; doing it is the only thing that counts. Daniel F. Chambliss, Champions: The Making of Olympic Swimmers

\section{INTRODUCTION}

As in the old Hans Christian Andersen tale about the gullible emperor (Andersen and Tudor, 1945), people the world over have been duped through the power of suggestion (Thomas, 1928) into believing that

\footnotetext{
${ }^{1}$ Note: Authors contributed equally. Names are listed in alphabetical order. Address correspondence to: Earl Smith; e-mail: smithearl8@gmail.com.
} 